\title{
サケ中骨のカルシウム吸収に対する加工方法の影響
}

\author{
秋野雅樹 \&，蛯谷幸司*，今村玩磨，内山智幸**，松嶋景一郎**，原＼cjkstart博*** \\ 北海道立網走水産試験場加工利用部 \\ $*$ 北海道立網走水産試験場加工利用部（現 : 釧路水産試験場利用部） \\ ** 北海道立工業試験場 \\ *** 北海道大学大学院農学研究院
}

\section{Effects of Salmon Bone Processing Methods on Intestinal Calcium Absorption in Rats}

\author{
Masaki Akino ${ }^{\S}$, Kouji Ebitani*, Takuma Imamura, Tomoyuki Uchiyama**, \\ Keiichiro Matsushima** and Hiroshi Hara*** \\ Processing and Utilization Division, Hokkaido Abashiri Fisheries \\ Experiment Station, 7-8-5 Minato-cho, Monbetsu 094-0011 \\ * Processing and Utilization Division, Hokkaido Abashiri Fisheries Experiment Station, 7-8-5 \\ Minato-cho, Monbetsu 094-0011 (Present : Utilization Division, Hokkaido Kushiro \\ Fisheries Experiment Station, 4-25 Nakahama-cho, Kushiro 085-0027) \\ ** Hokkaido Industrial Research Institute, Kita-19, Nishi-11, Kita-ku, Sapporo 060-0819 \\ *** Graduate School of Agriculture, Hokkaido University, Kita-9, Nishi-9, Kita-ku, Sapporo 060-8589
}

The aim of the present study was to utilize salmon bones, by-products of salmon processing, as a calcium supplement. We examined the effects of processing methods of salmon bones, especially degrees of pulverization and refining, on calcium absorption using a rat balance study (5-week-old male SpragueDawley rats). Using different pulverization and refining conditions, salmon bone powders were prepared and added to test diets based on mineral formulation of the AIN-93G diet. We found that ultrafine pulverization of salmon bones improved calcium absorption in rats and that semi-refined salmon bone powder, i.e., materials containing calcium with a large amount of salmon bone protein, had the potential to enhance calcium absorption. Thus, salmon bone may be an excellent resource for a calcium supplement, and the ultrafine pulverization and preparation, including that of bone protein, can enhance bioavailability of salmon bone calcium.

(Received Aug. 27, 2008 ; Accepted Dec. 12, 2008)

Keywords : calcium, calcium absorption, processing method, rat, salmon bone

キーワード : カルシウム，カルシウム吸収，加工方法，ラット，サケ中骨

北海道はサケの産地としてよく知られている。サケの漁 獲量や漁業生産額は高く，北海道の水産業に果たす役割は 大きい。 サケの用途は広く, 生鮮や冷凍の他, 塩蔵品（新 巻, 山漬), 乾製品 (トバ), フレーク, 缶詰等の加工製品 の原料としても利用される.

近年, サケの流通形態がラウンドやドレス出荷に加えて フィレー形態での出荷も増加していることから, 中骨等の 加工残㳯が多量に産出されている。 サケ中骨 (以下中骨) については，食品素材としての利用は非常に少ない。しか し, 魚骨は食用することが可能ならば極めて優秀な天然力

干094-0011 紋別市港町 7-8-5

* $\mathbf{T} 085-0027$ 釧路市仲浜町 4-25

** ₹060-0819 札幌市北区北 19 条西 11 丁目

*** 个060-8589 札幌市北区北 9 条西 9 丁目

$\S$ 連絡先 (Corresponding author), akinom@fishexp.pref.hokkaido.jp
ルシウム $(\mathrm{Ca})$ ソースであり ${ }^{1)}$, 天然 $\mathrm{Ca}$ にこだわりを持つ ユーザーには人気がある ${ }^{2)}$ そのうえ，Ca の主な供給源で ある乳製品や小魚, 大豆などは, 現在の食事では減少傾向 にあり, 日本人の $\mathrm{Ca}$ 平均摂取量はかなり低い摂取レベル にあるといえる，将来，骨粗鬆症など骨疾病の大幅な増加 が危惧される3).このため中骨は天然 $\mathrm{Ca}$ 素材としての栄 養補助食品への利用が期待される.

中骨の利活用に際して，中骨は食品素材として好まれる 外観ではなく，なにより直接可食することが難しいことか ら，食用に適した形状にすることが必要とされる。さらに 魚骨の栄養学的な利用効率, すなわち消化吸収性の優れた 加工・調理または摂取方法の技術開発が望まれる。これま で，魚骨の軟化や可食化に関する研究は，いくつか報告さ れているが4) 6)，実際に Ca 補助食品として利用するため 
の詳細な加工方法, 特に粉砕や精製の条件について言及さ れ，それらが Ca 吸収に及ぼす影響に関して報告されている ものはない.

本研究では, 微細化食品素材の開発の一環として, サケ 中骨の加工方法がラットの Ca 吸収に及ぼす影響について 検証した.

\section{実 験 方 法}

\section{1. 供試試料}

北海道紋別市内の水産加工場から入手したシロサケ Oncorhyncus keta 中骨の加工残滓を用いた。これらは試 験に供するまでー $30^{\circ} \mathrm{C}$ で保存した。

\section{2. 中骨 $\mathrm{Ca}$ 素材の調製}

(1) 酵素処理

中骨を包丁で細切した後, 電動式ミートチョッパー（大 道産業(株) 製, OMC-22) で粉砕した。 この粉砕物に残存 するサケ筋肉組織等の共雑物を簡易的に除去するために, 試料重量に対して 3 倍量の水と $0.5 \%(\mathrm{v} / \mathrm{w})$ のアルカラー

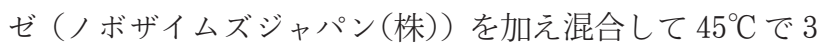
時間, 酵素処理した. その後, 沈殿物を回収し, 沸騰水で 10 分間加熱して酵素を失活させた. 酵素処理した中骨の一 部は, $50^{\circ} \mathrm{C}$ で約 20 時間熱風乾燥した後, 石臼式摩砕機 (増 幸産業(株) 製, スーパーマスコロイダーMKZA6-5), 次に アトマイザーミル (ホソカワミクロン(株) 製, マイクロバ ンタムミル AP-B型) で微細化し, さらにジェットミル （日清エンジニアリング(株) 製, CJ-10）により超微細化処 理を行った。これを骨タンパク質を含有する粗精製超微細 化サケ中骨粉末 (以下 SR-USBP) の Ca 素材とし, 動物試 験（実験 2）への供試試料とした。

\section{(2) アルカリ処理}

酵素処理した中骨の残りは, 骨タンパク質を徹底的に除 去するためアルカリ処理を行った. アルカリ処理の条件 は, 酵素処理物を円筒形プラスチックカラム（ $\mathrm{mm}$ ）に充填し, 試料重量に対して 4 倍量の $2 \mathrm{~mol} / \mathrm{L}$ 水酸 化ナトリウム溶液を $40^{\circ} \mathrm{C}$ に保温し, 定量送液ポンプ（東京 理科器械(株) 製, RP-2000）を使用して $300 \mathrm{~mL} / \mathrm{min}$ で 6 時間循環させた. アルカリ処理後, 円筒形プラスチックカ ラムを水道蛇口に接続し流水により $\mathrm{pH}$ が中性付近になる まで洗浄した。 その後, カラム内からアルカリ処理物を ビーカーに回収し, 蒸留水でデカンテーションを数回繰り 返して洗浄した。アルカリ処理した中骨は, $50^{\circ} \mathrm{C} て ゙$ 約 18 時間熱風乾燥した後, 乳鉢を用いて摩砕した。摩砕した中 骨は，ステンレス製ふるい（東京スクリーン(株) 製)を用 いてふるい分けし, 目開き $125 \sim 250 \mu \mathrm{m}$ の範囲で回収した サイズを微細化サケ中骨粉末（以下 FSBP, 実験 1）の Ca 素材とした。

一方，目開き $125 \mu \mathrm{m}$ 以下で回収した中骨は，ジェット ミルにより超微細化処理を行い, 超微細化サケ中骨粉末
Table 1 Characteristics of raw material and salmon bone powders

\begin{tabular}{lcrrr}
\hline \hline & Raw material & SR-USBP & FSBP & USBP \\
\hline $\begin{array}{l}\text { Particle size, } \mathrm{D}_{50} \\
\quad(\mu \mathrm{m})\end{array}$ & - & 3.8 & 128.4 & 1.9 \\
\hline Moisture (\%) & 58.0 & 2.2 & 6.7 & 4.2 \\
Crude protein $(\%)$ & 18.6 & 28.3 & 0.5 & 0.6 \\
Crude fat (\%) & 6.6 & 0.6 & 0.2 & 0.2 \\
Crude ash (\%) & 15.9 & 62.9 & 85.2 & 88.1 \\
\hline $\mathrm{Ca}(\%)$ & 5.90 & 26.25 & 33.22 & 35.80 \\
$\mathrm{P}(\%)$ & 2.91 & 11.76 & 15.30 & 15.82 \\
$\mathrm{Mg}(\%)$ & 0.11 & 0.40 & 0.55 & 0.51 \\
$\mathrm{Na}(\%)$ & 0.22 & 0.20 & 0.21 & 0.43 \\
\hline
\end{tabular}

SR-USBP, semi-refined ultrafine salmon bone powder; FSBP, fine salmon bone powder; USBP, Ultrafine salmon bone powder.

（以下 USBP, 実験 1，2）の Ca 素材とした.これら二つの Ca 素材は動物試験への供試試料とした。

\section{3. 中骨 $\mathrm{Ca}$ 素材の粒径評価}

中骨 $\mathrm{Ca}$ 素材の粒度分布をレーザー回折・散乱法（日機 装(株) 製, 9320HAR (X-100)) により測定し, その平均粒 径 $\mathrm{D}_{50}$ を求めた (Table 1).

\section{4. 中骨の成分分析}

水分量は $105^{\circ} \mathrm{C}$ における常圧乾燥法, 粗タンパク質量は ケルダール法によって全窒素量を求め, 係数 6.25 を乗じて 算出した。粗脂肪量はソックスレー抽出法により定量し た. 無機成分は $550^{\circ} \mathrm{C}$ で 24 時間, 乾式灰化して原子吸光光 度法により定量した。ただし，リン（P）については上記条 件にて灰化後塩化物として, バナドモリブデン酸吸光光度 法7)で定量した。

\section{5. 実験動物および飼育条件}

5 週齢の Sprague-Dawley 系雄ラット(日本 SLC(株)), 初体重 $120 \mathrm{~g}$ 程度の屯のを用いた. ラットの飼育は, 個別の ステンレス製金網ケージにて，室温 $22 \pm 2^{\circ} \mathrm{C}$, 相対湿度 $40-$ 60\%, 明暗周期（明期 8:00-20:00, 暗期 20:00-8 :00) で行った。予備飼育として上記条件にて 1 週間程度 AIN93G ${ }^{8)}$ を基本とした標準飼料と脱イオン水を自由摂取させ た。また, 飼料給餌は粉末給餌器を使用して行った。試験 はすべて北海道大学大学院農学研究科実験動物委員会の承 認を得た上で, 北海道大学実験動物ガイドラインに沿って 行われた。

\section{Ca 出納実験}

(1) 中骨 $\mathrm{Ca}$ 素材の粉砕程度の差異がラットの $\mathrm{Ca}$ 吸収に 及ぼす影響（実験 1)

実験 1 では，ラットを予備飼育後，平均体重が均一にな るように 1 群 8 匹で 4 群に分けた。 ラットには飼料とし て, AIN-93G をそのまま用いた標準食 (Control 1), ミネラ ル組成を中骨群に合わせて改変した対照食 (Control 2), 
Table 2 Mineral mixes that supply the concentrations of minerals for the test diets

\begin{tabular}{|c|c|c|c|c|c|}
\hline Ingredient & $\begin{array}{l}\text { Control } \\
1-\mathrm{MX}^{* 1}\end{array}$ & $\begin{array}{l}\text { Control } \\
2-\mathrm{MX}^{* 2}\end{array}$ & $\begin{array}{l}\text { SR-USBP- } \\
\mathrm{MX}^{* 2}\end{array}$ & $\begin{array}{l}\text { FSBP- } \\
\mathrm{MX}^{* 2}\end{array}$ & $\begin{array}{l}\text { USBP- } \\
\mathrm{MX}^{* 2}\end{array}$ \\
\hline & & & $\mathrm{g} / \mathrm{kg} \operatorname{mix}$ & & \\
\hline Calcium carbonate, anhydrous, $40.04 \% \mathrm{Ca}$ & 357.00 & 357.00 & - & - & - \\
\hline SR-USBP, $26.25 \% \mathrm{Ca} ; 11.76 \% \mathrm{P} ; 0.40 \% \mathrm{Mg} ; 0.20 \% \mathrm{Na}$ & - & - & 544.52 & - & - \\
\hline FSBP, $33.22 \% \mathrm{Ca} ; 15.30 \% \mathrm{P} ; 0.55 \% \mathrm{Mg} ; 0.21 \% \mathrm{Na}$ & - & - & - & 430.29 & - \\
\hline USBP, $35.80 \% \mathrm{Ca} ; 15.82 \% \mathrm{P} ; 0.51 \% \mathrm{Mg} ; 0.43 \% \mathrm{Na}$ & - & - & - & - & 399.27 \\
\hline Potassium phosphate, monobasic, $22.76 \% \mathrm{P} ; 28.73 \% \mathrm{~K}$ & 196.00 & 207.67 & 7.90 & - & 11.73 \\
\hline Sodium dihydrogenphosphate, dihydrate, $19.85 \% \mathrm{P} ; 14.63 \% \mathrm{Na}$ & - & 93.54 & - & - & - \\
\hline Potassium citrate, tri-potassium, monohydrate, $36.16 \% \mathrm{~K}$ & 70.78 & 61.50 & 220.21 & 26.50 & 217.18 \\
\hline Sodium chloride, $39.34 \% \mathrm{Na} ; 60.66 \% \mathrm{Cl}$ & 74.00 & 39.20 & 71.24 & 71.70 & 69.64 \\
\hline Magnesium oxide, $60.32 \% \mathrm{Mg}$ & 24.00 & - & 18.49 & 18.50 & 17.62 \\
\hline Magnesium chloride hexahydrate, $11.96 \% \mathrm{Mg} ; 17.44 \% \mathrm{Cl}$ & - & 121.05 & 9.60 & 8.00 & 15.20 \\
\hline Potassium sulfate, $44.87 \% \mathrm{~K} ; 18.39 \% \mathrm{~S}$ & 46.60 & 46.60 & 46.60 & 46.60 & 46.60 \\
\hline Ferric citrate, $16.5 \% \mathrm{Fe}$ & 6.06 & 6.06 & 6.06 & 6.06 & 6.06 \\
\hline Zinc carbonate, $52.14 \% \mathrm{Zn}$ & 1.65 & 1.65 & 1.65 & 1.65 & 1.65 \\
\hline Manganous carbonate, $47.79 \% \mathrm{Mn}$ & 0.63 & 0.63 & 0.63 & 0.63 & 0.63 \\
\hline Cupric carbonate, $57.47 \% \mathrm{Cu}$ & 0.30 & 0.30 & 0.30 & 0.30 & 0.30 \\
\hline Potassium iodate, $59.3 \%$ I & 0.01 & 0.01 & 0.01 & 0.01 & 0.01 \\
\hline Sodium selenate, anhydrous, $41.79 \% \mathrm{Se}$ & 0.0103 & 0.0103 & 0.0103 & 0.0103 & 0.0103 \\
\hline Ammonium paramolybdate, 4 hydrate, $54.34 \%$ Mo & 0.008 & 0.008 & 0.008 & 0.008 & 0.008 \\
\hline Sodium meta-silicate, 9 hydrate, $9.88 \% \mathrm{Si}$ & 1.45 & 1.45 & 1.45 & 1.45 & 1.45 \\
\hline Chromium potassium sulfate, 12 hydrate, $10.42 \% \mathrm{Cr}$ & 0.275 & 0.275 & 0.275 & 0.275 & 0.275 \\
\hline Lithium chloride, $16.38 \% \mathrm{Li}$ & 0.0174 & 0.0174 & 0.0174 & 0.0174 & 0.0174 \\
\hline Boric acid, $17.5 \% \mathrm{~B}$ & 0.0815 & 0.0815 & 0.0815 & 0.0815 & 0.0815 \\
\hline Sodium fluoride, $45.24 \% \mathrm{~F}$ & 0.0635 & 0.0635 & 0.0635 & 0.0635 & 0.0635 \\
\hline Nickel carbonate, $45 \% \mathrm{Ni}$ & 0.0318 & 0.0318 & 0.0318 & 0.0318 & 0.0318 \\
\hline Ammonium vanadate, $43.55 \% \mathrm{~V}$ & 0.0066 & 0.0066 & 0.0066 & 0.0066 & 0.0066 \\
\hline Powdered sucrose & 221.026 & 62.846 & 70.846 & 187.816 & 212.166 \\
\hline
\end{tabular}

Abbreviations are explained in the first footnote in Table 1.

*1 The control 1-mix was prepared in accordance with the AIN-93G-mix formulation.

*2 These mineral mixes supply only $2304 \mathrm{mg} \mathrm{P} / \mathrm{kg}$ diet. The remainder comes from casein which contains an average of $0.72 \% \mathrm{P}$. The amount of total phosphorus in test diets is $3744 \mathrm{mg} / \mathrm{kg}$.

FSBP 食, USBP 食のいずれか一つを摂食させた。標準食 を除いた他の飼料のミネラル混合物組成は, 中骨から調製 した各中骨 Ca 素材の無機成分の分析結果 (Table 1) を基 に飼料間の $\mathrm{P}$ 含有量を一定にし, P を除く他のミネラル成 分が AIN-93Gのミネラル混合物と等量になるように設定 した (Table 2). なお，これら飼料での $\mathrm{Ca} / \mathrm{P}$ はモル比で 1.0 となった。飼料の配合組成は Table 3 に示した. 試験飼 育は 2 週間行い, 脱イオン水は自由摂取とした. Ca 出納を 調査するために試験飼育を開始して 4 日目と 11 日目から ケージ下のトレーに Ca を含まない紙を敷き, それぞれ連 続して 4 日間の糞便を採取した。 4 日間の期間で 2 回に 亘って集められた糞便は凍結乾燥した後, 重量を測定し た。 各ラットの体重と摂食量は毎日測定した。試験飼育終 了日に，ラットをネンブタール麻酔下で開腹し，腹部大動 脈からへパリン採血した。大動脈より放血屠殺した後, 腎 臓および左大腿骨を摘出した。血漿は血液を $4{ }^{\circ} \mathrm{C}$ で遠心分 離 (3000 rpm, 10 分間) することにより分離し, 分析まで $-40^{\circ} \mathrm{C}$ で凍結保存した。腎臓および大腿骨は凍結乾燥した 後, 重量を測定した。

（2）中骨の精製処理の差異がラットの Ca 吸収に及ぼす 影響（実験 2)

実験 2 では, 飼料の配合組成以外の条件および手順につ いてはすべて実験 1 と同様に行った。 飼料については, 中 骨 Ca 素材を超微細化した効果をより明確にするために, 炭酸水素ナトリウムを添加することで消化性を抑える飼料 の配合組成を設計した（Table 3). 炭酸水素ナトリウムの 添加量は, AIN-93Gのミネラル混合物に含まれるナトリウ ム量と炭酸水素ナトリウムのナトリウム量が等量になるよ う設定した。 ラットには飼料として, 標準食 (Control 1), 対照食 (Control 2), SR-USBP 食, USBP 食のいずれか一 つを摂食させた。

\section{7. 動物実験試料の $\mathrm{Ca}$ 量分析と $\mathrm{Ca}$ 吸収率の算出}

凍結乾燥した粪便, 腎臓, 大腿骨の $\mathrm{Ca}$ 量は原子吸光光 度法により定量した. 血漿の $\mathrm{Ca}$ 濃度は, カルシウム $\mathrm{C}$-テ 
Table 3 Compositions of test diets

\begin{tabular}{|c|c|c|}
\hline Ingredient & Expreiment 1 & Expreiment 2 \\
\hline & \multicolumn{2}{|c|}{$\mathrm{g} / \mathrm{kg}$ diet } \\
\hline Casein*1 & 200.0 & 200.0 \\
\hline Dextrin $* 2$ & 529.5 & 525.8 \\
\hline Sucrose & 100.0 & 100.0 \\
\hline Soybean oil & 70.0 & 70.0 \\
\hline Mineral mix ${ }^{* 3}$ & 35.0 & 35.0 \\
\hline Vitamin $\operatorname{mix}^{* 4}$ & 10.0 & 10.0 \\
\hline Choline bitartrate & 2.5 & 2.5 \\
\hline L-Cystine & 3.0 & 3.0 \\
\hline Tert-butylhydroquinone & 0.014 & 0.014 \\
\hline Crystallized cellulose ${ }^{* 5}$ & 50.0 & 50.0 \\
\hline Sodium hydrogen carbonate ${ }^{* 6}$ & - & 3.7 \\
\hline
\end{tabular}

${ }^{* 1}$ ALACID (New Zealand Dairy Board, Wellington, New Zealand)

*2TK-16 (Matsutani Chemical Industry Co., Ltd., Hyogo, Japan).

${ }^{* 3}$ The mineral mix for control 1 diet was prepared in accordance with the AIN-93G formulation. Mineral mixes for other test diets were prepared in accordance with the composition shown in Table 2, and it provided (mg/ $\mathrm{kg}$ diet) : Ca 5000, P 2304, K 3600, S 300, Na 1019, Cl 1571, Mg 507, Fe 35.0, Zn 30.0, Mn 10.0, Cu 6.0, I 0.2, Mo 0.15, Se 0.15, Si 5.0, Cr 1.0, F 1.0, Ni 0.5, B 0.5, Li 0.1, V 0.1.

${ }^{* 4}$ The vitamin mix was prepared in accordance with the AIN-93G formulation.

${ }^{* 5}$ Avicel PH102 (Asahi Chemical Industry Co., Ltd., Tokyo, Japan)

${ }^{* 6}$ It provided (mg/kg diet) : Na 1019 .
ストワコー（和光純薬工業(株））で測定した.

Ca 吸収率は次の式により算出した：

$$
\begin{aligned}
& \mathrm{Ca} \text { 吸収率 }(\%) \\
& =([\text { 摂取 } \mathrm{Ca} \text { 量 }- \text { 糞中排泄 } \mathrm{Ca} \text { 量 }] / \text { 摂取 } \mathrm{Ca} \text { 量 }) \times 100
\end{aligned}
$$

\section{8. 統計学的処理}

図抽よび表の各值は平均值士標準誤差 (SEM) で示し た. 群間の差を一元もしくは二元配置の分散分析で解析

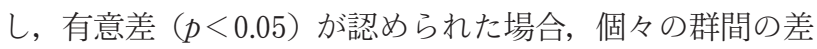
をDuncan の多重比較検定法により解析した.

\section{実 験 結 果}

\section{1. 中骨 $\mathrm{Ca}$ 素材の粉砕程度の差異がラットの $\mathrm{Ca}$ 吸収 に及ぼす影響（実験 1）}

実験 1 でのラットの成長パラメータを Table 4 に示し た. 2 週間の試験飼育で体重増加, 飼料摂取量に関して, 4 群間での有意差はみられなかった。

実験 1 でのラットの Ca 吸収量と $\mathrm{Ca}$ 吸収率については, 4 群間での有意差は認められなかった（Table 5).

さらに, FSBP 群と USBP 群の Ca 吸収率值を抽出し, 出納期間之粉砕程度を变動要因とする二元配置分散分析で 解析した結果, 前者 $(p=0.397)$ についての有意差は認め られなかったが, 後者 $(p<0.05)$ については有意差が認め られ，中骨 $\mathrm{Ca}$ 素材の粒径が Ca 吸収に影響を及ぼした (Fig. 1)。また，両者の相互作用 $(p=0.911)$ は認められな かった.

実験 1 で試験飼育後のラットの大腿骨と腎臟の相対重量 および大腿骨，腎臟，血漿中の Ca 濃度について 4 群間で の有意差はみられなかった（Table 6).

Table 4 Growth parameters in rats fed test diets (Experiment 1 and 2)

\begin{tabular}{lcccc}
\hline \multicolumn{1}{c}{ Diet group } & Initial body weight & Final body weight & Body weight gain & Food intake \\
\hline Experiment 1 & $\mathrm{g}$ & $\mathrm{g}$ & $\mathrm{g} /$ day & $\mathrm{g} /$ day \\
Control 1 & $161 \pm 3$ & $274 \pm 6$ & $8.1 \pm 0.3$ & $18.2 \pm 0.5$ \\
Control 2 & $161 \pm 3$ & $273 \pm 5$ & $8.0 \pm 0.3$ & $18.5 \pm 0.5$ \\
FSBP & $161 \pm 2$ & $279 \pm 8$ & $8.4 \pm 0.4$ & $18.6 \pm 0.7$ \\
USBP & $161 \pm 2$ & $276 \pm 4$ & $8.2 \pm 0.2$ & $18.8 \pm 0.3$ \\
one-way ANOVA & & & & \\
$P$ value & 1.000 & 0.875 & 0.662 & 0.869 \\
\hline Experiment 2 & $\mathrm{g}$ & $\mathrm{g}$ & $\mathrm{g} / \mathrm{day}$ & $\mathrm{g} / \mathrm{day}$ \\
Control 1 & $168 \pm 2$ & $274 \pm 5$ & $7.5 \pm 0.3$ & $18.1 \pm 0.4$ \\
Control 2 & $168 \pm 2$ & $286 \pm 5$ & $8.4 \pm 0.3$ & $19.3 \pm 0.6$ \\
SR-USBP & $169 \pm 2$ & $281 \pm 5$ & $8.2 \pm 0.2$ & $18.7 \pm 0.4$ \\
USBP & $169 \pm 2$ & $284 \pm 4$ & $8.1 \pm 0.3$ & $18.9 \pm 0.3$ \\
one-way ANOVA & & & & \\
$P$ value & 0.993 & 0.309 & 0.125 & 0.282 \\
\hline
\end{tabular}

All values are means \pm SEM, $n=8$ except for the group of rats fed the USBP diet of experiment $2(\mathrm{n}=7)$.

Abbreviations are explained in the first footnote in Table 1. 
Table 5 Calcium absorption in rats fed test diets diets in the 1st period (d 4-7 of the feeding period) and 2nd period (d 11-14 of the feeding period) (Experiment 1 and 2)

\begin{tabular}{|c|c|c|c|c|}
\hline \multirow[b]{2}{*}{ Diet group } & \multicolumn{2}{|c|}{ Net $\mathrm{Ca}$ absorption } & \multicolumn{2}{|c|}{$\mathrm{Ca}$ absorption rate } \\
\hline & days $4-7$ & days $11-14$ & days $4-7$ & days $11-14$ \\
\hline Experiment 1 & \multicolumn{2}{|c|}{$\mu \mathrm{mol} / 4 \mathrm{~d}$} & \multicolumn{2}{|c|}{$\%$} \\
\hline Control 1 & $6.46 \pm 0.19$ & $7.33 \pm 0.25$ & $76.4 \pm 1.6$ & $74.1 \pm 1.4$ \\
\hline Control 2 & $6.62 \pm 0.16$ & $7.60 \pm 0.22$ & $78.7 \pm 1.6$ & $75.5 \pm 1.1$ \\
\hline FSBP & $6.56 \pm 0.18$ & $7.22 \pm 0.16$ & $75.3 \pm 2.7$ & $73.3 \pm 2.5$ \\
\hline $\begin{array}{l}\text { USBP } \\
\text { one-way ANOVA }\end{array}$ & $6.54 \pm 0.20$ & $7.34 \pm 0.20$ & $79.7 \pm 1.5$ & $78.2 \pm 1.2$ \\
\hline$P$ value & 0.948 & 0.631 & 0.360 & 0.194 \\
\hline Experiment 2 & \multicolumn{2}{|c|}{$\mu \mathrm{mol} / 4 \mathrm{~d}$} & \multicolumn{2}{|c|}{$\%$} \\
\hline Control 1 & $7.27 \pm 0.19$ & $7.54 \pm 0.32$ & $77.4 \pm 2.2 \mathrm{c}$ & $72.4 \pm 2.8 \mathrm{~b}$ \\
\hline Control 2 & $7.42 \pm 0.19$ & $8.18 \pm 0.22$ & $78.2 \pm 1.7 \mathrm{bc}$ & $73.8 \pm 1.5 \mathrm{~b}$ \\
\hline SR-USBP & $6.86 \pm 0.13$ & $7.39 \pm 0.23$ & $85.0 \pm 1.3 \mathrm{a}$ & $80.9 \pm 1.6 \mathrm{a}$ \\
\hline $\begin{array}{l}\text { USBP } \\
\text { one-way ANOVA }\end{array}$ & $6.93 \pm 0.16$ & $7.60 \pm 0.23$ & $80.2 \pm 1.8 \mathrm{~b}$ & $78.1 \pm 1.6 \mathrm{a}$ \\
\hline$P$ value & 0.081 & 0.155 & 0.021 & 0.018 \\
\hline
\end{tabular}

All values are means \pm SEM, $n=8$ except for the group of rats fed the USBP diet of experiment $2(\mathrm{n}=7)$.

Abbreviations are explained in the first footnote in Table 1.

Values in a column not sharing a common letter are significantly different at $p<0.05$.

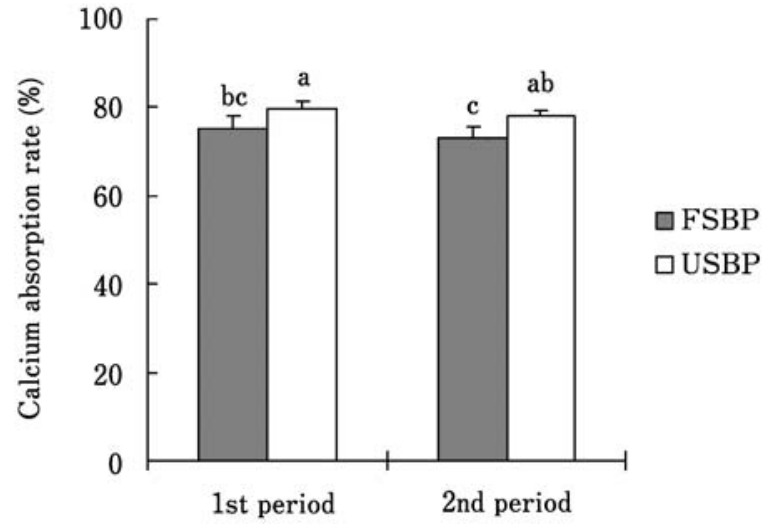

Fig. 1 Calcium absorption rate in rats fed the fine salmon bone powder (FSBP) or ultrafine salmon bone powder (USBP) diets in the 1st period (d 4-7 of the feeding period) and 2nd period (d 1114 of the feeding period) (Experiment 1).

Values are means \pm SEM, $n=8$. Values not sharing a common letter are significantly different at $p<0.05$. $P$-values estimated by two-way ANOVA were 0.397 for period, 0.033 for pulverization and 0.911 for period $\times$ pulverization.

\section{2. 中骨の精製処理の差異がラットの $\mathrm{Ca}$ 吸収に及ぼす 影響（実験 2)}

実験 2 でのラットの成長パラメータは, 実験 1 の結果と 同様に 4 群間での有意差はみられなかった（Table 4).

実験 2 で 4 群間の Ca 吸収量については有意差が認めら れなかったが，Ca吸収率については有意差が認められ，SR-
USBP 群が最も高い值を示した（Table 5).

さらに, SR-USBP 群と USBP 群の Ca 吸収率值を抽出 し, 出納期間と精製処理を变動要因とする二元配置分散分 析で解析した結果, 前者 $(p=0.051)$ についての有意差は認 められなかったが, 後者 $(p<0.05)$ ついては有意差が認め られ，USBP 群より SR-USBP 群で Ca 吸収率が有意に高 值であった（Fig. 2). また，相互作用 $(p=0.517)$ は認めら れなかった。

実験 2 で試験飼育後のラットの大腿骨と腎臓の相対重量 および大腿骨, 腎臓, 血漿中の $\mathrm{Ca}$ 濃度について 4 群間で の有意差は認められなかった（Table 6).

\section{考察}

魚骨の Ca は, 主に結晶性ヒドロキシアパタイト (HAp) $\mathrm{Ca}_{10}\left(\mathrm{PO}_{4}\right)_{6}(\mathrm{OH})_{2}$ と呼ばれるリン酸カルシウムの形で存 在し，骨中の $\mathrm{Ca}: \mathrm{P}$ 比率は，ほぼ $2: 1$ である ${ }^{9)}$.

本研究では，中骨素材を $\mathrm{Ca}$ ソースとする $0.5 \% \mathrm{Ca}$ 飼料 を調製したため, 飼料中の P 含有量は, AIN93-G 飼料より 多くなった。 AIN-93G 飼料では， $\mathrm{Ca} / \mathrm{P}$ はモル比で 1.3 に 設定されているが8), 本研究で使用した飼料では 1.0 で あった．そのため，試験を実施するに当たり，ミネラル混 合の改変による試験飼育への影響を調べるため, ミネラル を中骨群に合わせて改变した対照群 (Control 2) の他に, AIN-93G をそのまま用いた標準食とする 1 群 (Control 1) を加えて実験系を設定した。

実験 1 では，これら 2 群間でのラットの体重増加，飼料 
Table 6 The relative weights of femur and kidney and calcium concentrations in femur, kidney and plasma in rats fed test diets (Experiment 1 and 2)

\begin{tabular}{|c|c|c|c|c|c|}
\hline Diet group & Femur dry weight & $\begin{array}{c}\text { Ca concentration } \\
\text { in femur }\end{array}$ & Kidney dry weight & $\begin{array}{l}\text { Ca concentration } \\
\text { in kidney }\end{array}$ & $\begin{array}{l}\text { Plasma Ca } \\
\text { concentration }\end{array}$ \\
\hline Experiment 1 & $\mathrm{mg} / 100 \mathrm{~g}$ body $\mathrm{wt}$ & $\mathrm{mmol} / \mathrm{g}$ dry femur & $\mathrm{mg} / 100 \mathrm{~g}$ body wt & $\mu \mathrm{mol} / \mathrm{g}$ dry kidney & $\mathrm{mg} / \mathrm{dL}$ \\
\hline Control 1 & $126 \pm 2$ & $5.31 \pm 0.03$ & $162 \pm 4$ & $5.42 \pm 0.15$ & $12.6 \pm 0.3$ \\
\hline Control 2 & $123 \pm 2$ & $5.39 \pm 0.04$ & $162 \pm 3$ & $5.43 \pm 0.18$ & $13.0 \pm 0.2$ \\
\hline FSBP & $122 \pm 3$ & $5.37 \pm 0.06$ & $159 \pm 2$ & $5.34 \pm 0.26$ & $12.7 \pm 0.2$ \\
\hline USBP & $123 \pm 2$ & $5.34 \pm 0.06$ & $162 \pm 2$ & $5.56 \pm 0.12$ & $12.7 \pm 0.3$ \\
\hline \multicolumn{6}{|l|}{ one-way ANOVA } \\
\hline$P$ value & 0.563 & 0.660 & 0.756 & 0.870 & 0.547 \\
\hline Experiment 2 & $\mathrm{mg} / 100 \mathrm{~g}$ body wt & $\mathrm{mmol} / \mathrm{g}$ dry femur & $\mathrm{mg} / 100 \mathrm{~g}$ body wt & $\mu \mathrm{mol} / \mathrm{g}$ dry kidney & $\mathrm{mg} / \mathrm{dL}$ \\
\hline Control 1 & $125 \pm 2$ & $5.25 \pm 0.04$ & $165 \pm 3$ & $7.33 \pm 0.20$ & $12.2 \pm 0.4$ \\
\hline Control 2 & $122 \pm 3$ & $5.27 \pm 0.05$ & $163 \pm 2$ & $7.39 \pm 0.21$ & $12.9 \pm 0.2$ \\
\hline SR-USBP & $122 \pm 3$ & $5.24 \pm 0.07$ & $168 \pm 3$ & $7.05 \pm 0.16$ & $12.4 \pm 0.3$ \\
\hline USBP & $123 \pm 3$ & $5.23 \pm 0.06$ & $163 \pm 2$ & $7.59 \pm 0.64$ & $12.6 \pm 0.3$ \\
\hline \multicolumn{6}{|l|}{ one-way ANOVA } \\
\hline$P$ value & 0.731 & 0.959 & 0.503 & 0.730 & 0.415 \\
\hline
\end{tabular}

All values are means \pm SEM, $n=8$ except for the group of rats fed the USBP diet of experiment $2(n=7)$. Abbreviations are explained in the first footnote in Table 1.

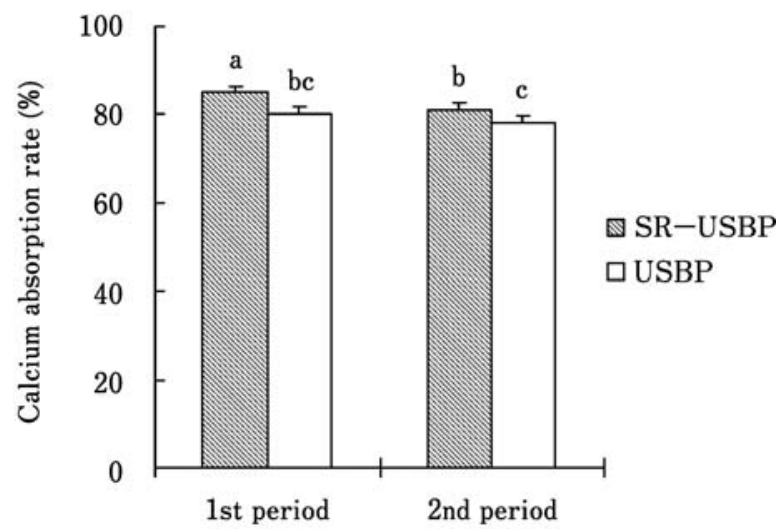

Fig. 2 Calcium absorption rate in rats fed the semirefined ultrafine salmon bone powder (SR-USBP) or ultrafine salmon bone powder (USBP) diets in the 1st period ( 4 $^{-7}$ of the feeding period) and 2nd period (d 11-14 of the feeding period) (Experiment 2).

Values are means \pm SEM, $\mathrm{n}=8$ in the SR-USBP diet group; $n=7$ in the USBP diet group. Values not sharing a common letter are significantly different at $p<0.05$. $P$-values estimated by two-way ANOVA were 0.051 for period, 0.022 for refining and 0.517 for period $\times$ refining.

摂食量についての有意差はみられず，ラットは順調に成長 した。また，すべての群間において飼育後の大腿骨と腎臓 の相対重量および大腿骨, 腎臟, 血漿中の $\mathrm{Ca}$ 濃度につい てあ群間での有意差はみられなかった。これらのことか ら, ミネラル混合を改変したことによる成長面での影響は ほとんどないと考えられ，飼料に配合した中骨 Ca 素材は 有効に利用されていることが示唆された。
実験 1 でのラットの Ca 吸収率については, 有意差はみら れなかった。この結果は, 中骨群のミネラルとして使用し た中骨 $\mathrm{Ca}$ 素材が，Control 群に使用した特級試薬の炭酸 カルシゥム（和光純薬工業(株)）と比較しても遜色のない 優れた Ca 素材であることを示している.

一方, 中骨の処理を比較するため, FSBP 群と USBP 群 の Ca 吸収率を二元配置分散分析により解析した結果, 粉 砕程度によって有意差が認められ, 中骨の超微細化処理が Ca 吸収を改善させることが確認された.

一般的に，Ca はイオンの状態で腸管内より吸収される と考えられている。 そのため生体における $\mathrm{Ca}$ 吸収では, $\mathrm{Ca}$ の溶解性が重要な決定要因の一つである ${ }^{10111)}$. そして 胃酸は, 食品中の $\mathrm{Ca}$ の大半を占める不溶性 $\mathrm{Ca}$ 塩を溶か して吸収させるために重要な役割を持っている ${ }^{12}$. 胃切除 ラットでの Ca 吸収率は, 溶解性の塩化カルシウムより不 溶性の炭酸カルシウムで著しく低下することが報告されて いる ${ }^{13)}$. 本研究において中骨 $\mathrm{Ca}$ 素材を超微細化したこと が, 胃でのCa の可溶化に対して有益に作用したと推察さ れる.

実験 2 に押いて，ラットの体重増加と飼料摂食量，そし て試験飼育後の大腿骨と腎臓の相対重量および大腿骨, 腎 臟, 血漿中の $\mathrm{Ca}$ 濃度については, 群間での有意差はみら れず, 実験 1 之同様に中骨 $\mathrm{Ca}$ 素材の有効性が示唆された.

実験 2 でのラットの Ca 吸収率は, 第 1 期および第 2 期 の出納期間で有意差が認められ, 両期間において Control 群より SR-USBP 群で有意に高く, Ca 素材してのSRUSBP の生体利用効率が高いことが確認された。また，実 験 2 では消化を抑制するために飼料に炭酸水素ナトリウム を添加したが, 実験 1 の結果と比較して, Control 群や 
USBP 群の Ca 吸収率がほとんど低下していないことか ら, 十分な効果は得られなかった。 これについては, 飼料 中の Ca ソースである炭酸カルシウム試薬とUSBP の平均 粒径が，それぞれ 11.9 および $1.9 \mu \mathrm{m}$ (レーザー回折・散乱 法分析）と, 粒子サイズが非常に微細であるために, Ca の 消化性での差は出にくいことが推察されるが, 炭酸水素ナ トリウムの添加量が少なすぎた可能性もある. しかし, 得 られた結果については, 実験 1 と同様の傾向を示し, 值も 近似していることから再現性のあることが確認された。

一方, 中骨の処理を比較するため, SR-USBP 群と USBP 群の Ca 吸収率を二元配置分散分析により解析した結果, 精製処理によって有意差が認められ, SR-USBP 群の Ca 吸収率が USBP 群より有意に高值であった。すなわち, こ の結果は中骨を $\mathrm{Ca}$ 素材として利用する場合, 骨タンパク 質を含有させて素材化することで, Ca 吸収立進作用が付 加されることを示唆している。

通常, 骨基質はコラーゲンを主体とした有機基質とそこ に沈着したHApから構成されていることから，この骨夕 ンパク質に関してもコラーゲンが主体であると考えられ る.コラーゲンについては，その分解物であるペプチドが Ca 吸収を促進することが報告されている ${ }^{14)}$ 。また, Jung らは, 魚骨タンパク質の分解物を HAp 処理等で分離した $\mathrm{Ca}$ 親和性の高いペプチドが不溶性 $\mathrm{Ca}$ 塩の生成を抑制し, 卵巣切除ラットでの $\mathrm{Ca}$ の生体利用性を高めることを報告 している ${ }^{15)}$. よって, 本研究においても SR-USBP が Ca 吸収を亢進させた要因として, 骨タンパク質の分解物であ る $\mathrm{Ca}$ 親和性のペプチドが Ca と結合して可溶性複合体を 形成したことで, $\mathrm{Ca}$ がリン酸と不溶性沈澱を形成するこ とを防止し, 小腸下部での拡散輸送による Ca吸収が高 まったと推察される. SR-USPB に施した超微細化処理は, その骨タンパク質の消化性を高め, ペプチドへの分解速度 やペプチド量を増加させる可能性があり, Ca とペプチド の可溶性複合体の形成を促進させたと考えられる。また， SR-USBP のような骨タンパク質と Ca 塩 (HAp) が結着 した形態は, $\mathrm{Ca}$ 生体利用性に優れている可能性が示唆さ れた。これは, SR-USBP の飼料中に含まれる中骨由来の タンパク質量が飼料組成より算出して飼料 $1 \mathrm{~kg}$ 当たり 5.4 $\mathrm{g}$ と少量であったにもかかわらず，効果がみられたことが この可能性を支持する. しかしながら, 本研究では, 中骨 Ca 素材に含まれる骨タンパク質が Ca によ゙のように作用 して Ca 吸収を六進させるのかについては, 詳細な検証を していないためその吸収機構は不明であり, 今後の研究に おける検討課題である。

以上のことから, 本研究において開発した中骨 $\mathrm{Ca}$ 素材 は, 超微細化処理の効果によって Ca 吸収が改善され, 骨 タンパク質を含有させることで Ca 吸収六進作用を付加さ れることが示唆され, 栄養補助食品としてそれ自体で, あ るいは他の食品と複合して利用することが期待できる.

\section{要 約}

本研究において, 我々は, 中骨の食用化への利用を図る ため, 中骨の Ca 素材を開発し, ラットでの Ca 出納実験よ りその消化吸収性を評価した。

実験 1 において，Ca吸収は，FSBP 群よりUSBP 群で 有意な高值が認められ, 超微細化処理された中骨 $\mathrm{Ca}$ 素材 が Ca 吸収を改善する効果が確認された。

実験 2 において, Ca 吸収は, USBP 群より SR-USBP 群 で有意な高值が認められ, 骨タンパク質を含有した中骨 Ca 素材が Ca 吸収元進作用を有することが示唆された。ま た, 実験を通して超微細化サケ中骨粉末が, 特級試薬レベ ルの炭酸カルシウムと比較しても遜色のない優れた Ca 素 材であることが明らかとなった。

本研究を遂行するに当たり, 動物試験についてのご指 導, ご助言を頂きました北海道大学大学院農学研究院食品 栄養学研究室石井麻友氏, ならびに解剖等にご助力頂きま した食品栄養学研究室の皆様に深謝します.

\section{文献}

1）太田静行, 魚の骨, New Food Industry, 23，66-72 (1981).

2) ミネラル食品・素材の市場動向, 「食品之開発」, (CMC ジャパン, 東京) 42, pp. 75-84 (2007).

3) 原 博, カルシウムの役割とその吸収一新しい展開, 化学 と生物， 46，412-419（2008).

4）渡辺尚彦, 武輪正彦, 高井陸雄, 酒井愿夫, 魚の骨のクッキ ングによる軟化速度, 日水誌，51，2047-2050（1985）。

5）畑江敬子, 大沼葉子, 島田淳子, サケ鼻軟骨のテクスチャー に及ぼす食䣷浸漬の影響, 日食工誌，37，505-510（1990).

6）平岡芳信, 城 敦子, 成田公義, 平山和子, 菅 忠明, 養殖 八マチ中骨のレトルト処理によるコラーゲンのゼラチン化 と軟化, 日水誌, 67, 261-266 (2001).

7）安井明美, リン,「新・食品分析法」, 新・食品分析法編集委 員会編, (光琳, 東京), pp. 257-259 (1996).

8) Reeves, P.G., Nielsen, F.H. and Fahey, G.C.Jr., AIN-93 purified diets for laboratory rodents : final report of the American Institute of Nutrition ad hoc writing committee on the reformulation of the AIN-76A rodent diet, $J$. Nutr., 123, 1939-1951 (1993).

9) Hamada, M., Nagai, T., Kai, N., Tanoue, Y., Mae, H., Hashimoto, M., Miyoshi, K., Kumagai, H., and Saeki, K., Inorganic constituents of bone of fish, Fish.sci., 61, 517520 (1995).

10) Duflos, C., Bellaton, C., Pansu, D. and Bronner, F., Calcium solubility, intestinal sojourn time and paracellular permeability codetermine passive calcium absorption in rats, J.Nutr., 125, 2348-2355 (1995).

11) Bronner, F. and Pansu, D., Nutritional aspects of calcium absorption, J.Nutr., 129, 9-12 (1999).

12）原博, 難消化性食品成分とそのミネラル吸収促進作用, New Food Industry, 35, 35-44 (2001).

13) Hara, H., Suzuki, T., Kasai, T., Aoyama, Y. and Ohta, A., Ingestion of guar gum hydrolysate, a soluble fiber, increases calcium absorption in totally gastrectomized rats, J.Nutr., 129, 39-45 (1999). 
14）吉岡和男, 杉原富人, 山本憲朗, 中野清一, 室山幸太郎, 力 ルシウム吸収促進剂およびその製造方法，特許第 3881453 号 2006.11.17)。

15) Jung, W.K., Lee, B.J. and Kim, S.K., Fish-bone peptide increases calcium solubility and bioavailability in ovariectomised rats, B. J.Nutr., 95, 124-128 (2006).

(平成 20 年 8 月 27 日受付, 平成 20 年 12 月 12 日受理) 